\title{
Guilford acquires Gliatech in strategic deal
}

On May 30, Guilford Pharmaceuticals (Baltimore, MD) announced that it has agreed to purchase the biotechnology firm Gliatech (Cleveland, $\mathrm{OH}$ ) for about \$203 million worth of shares. While neither company is floundering financially, merging their product portfolios, future product pipelines, and human resources should lead to better valuations and greater access to capital. More immediately, combined revenues from their biopolymer products will allow them to push forward a fuller neurology program, which although notoriously risky is potentially much more lucrative.

Under terms of the deal, Gliatech's shareholders will receive 1.38 Guilford shares for every Gliatech share held, and the combined company will have a market valuation of little over $\$ 500$ million. Although Guilford made a loss last year of $\$ 26.9$ million on a turnover of $\$ 21.6$ million, it has a relatively low cash burn rate and considerable cash in hand; Gliatech only narrowly missed breaking even for the first time last year. With a combined cash reserve of \$155 million, the merged company can comfortably tick over for the next four or five years.

According to Jonas Alsenas, a biotech analyst at ING Barings (New York), the two companies "fit like hand in glove". With three products on the market and nine in clinical and pre-clinical development, the combining of their complementary areas of expertise in biopolymers and experimental treatments for neurological conditions puts them more firmly on investors' radar screens.

One of the three revenue-generating biopolymer products is Guilford's Gliadel Wafer, the only product of its kind available for the treatment of recurrent glioblastoma (an aggressive type of brain cancer); the wafer is impregnated with a cytotoxic drug and placed in the cavity created after the brain tumour is removed. The others are Gliatech's Adcon-L and Adcon-T/N, gels used to prevent tissue adhesions after lumbar surgery and peripheral nerve surgery, respectively. Gliatech expects to launch a formulation of Adcon for abdominal and gynaecological surgery (Adcon-P) later this year.

This greater presence in the market for surgical biopolymers gives them a "competitive advantage," according to Adam Gridley, Gliatech's investor relations manager. The closest competition comes from Ridgefield, NJ-based Biomatrix, which is soon to be part of Genzyme BioSurgery and whose lead product has only just been approved to be tested in pivotal trials. In addition, Guilford's

Liz Fletcher is a freelance writer working in Cambridge, UK. future biopolymer products, which include Gliadel and Paclimer Microspheres, a biopolymer containing paclitaxel for the treatment of breast cancer, will benefit from Gliatech's 100-strong specialty sales team.

However, the biopolymer products will never enjoy blockbuster status: Adcon generated $\$ 29$ million in sales last year, but even with the best predictions-including the approval of new indications for the gel-it is unlikely to generate more than $\$ 200$ million at the most. Meanwhile Gliadel last year generated sales of about $\$ 20$ million, of which Guilford received only $\$ 6.8$ million, the rest going to its marketing partner Aventis (Frankfurt, Germany). Even if the FDA approves the use of the Wafer for first-line therapy of glioblastomas, sales are likely to peak at $\$ 100$ million- $\$ 200$ million.

Nevertheless, with a steady flow of increased revenue, the two companies can look to the future and focus on nurturing their neurology pipeline-a strategy that analysts consider "far sighted and mature".

Neurology is a high-risk area in that CNS products have the highest failure rates, according to biotech analyst Daniella Evans of CIBC (New York); yet the rewards are potentially enormous. With more leads, the merged company has more "shots at the goal," as Gliatech puts it.

One of these is Gliatech's Perceptin, a histamine $\mathrm{H} 3$ receptor antagonist indicated for the treatment of attention deficit hyperactivity disorder. Alone, Gliatech had insufficient resources to push forward Perceptin, which is

currently in phase II trials. Gliatech is also developing glial-based treatments for Alzheimer's disease and $\mathrm{H} 3$ antagonists for other conditions such as narcolepsy. Gliatech's association with Guilford will help salvage its neurology pipeline, which it considers was being overlooked by investors. (Gliatech's share price was noticeably unmoved in the recent biotech boom).

Guilford's lead neurology candidate is the neuroimmunophilin, NIL-A, which is indicated for the treatment of Parkinson's disease. It is currently in phase I, and has received about $\$ 48$ million in funding from Amgen (Thousand Oaks, CA). Guilford could, at least in theory, hit the jackpot with the neuroimmunophilins. As orally active drugs they could have advantages over stem cell therapies, which are the main competition in the field of neurodegenerative medicine. It is still far too early to say whether they will work, but Evans says that Amgen's partnership “is an important validation of the potential of the product". For now, Amgen is footing the bill, but Guilford and Gliatech should make the most of their financial honeymoon.

Most of both companies' drug candidates have been, and will continue to be, inlicensed. Guilford's other programs currently include agents to prevent nerve damage, anesthetics, and treatments for neuropathic pain and Alzheimer's disease, and a diagnostic test for Parkinson's disease. But if the neuroimmunophilins don't work out, another acquisition may be on the cards.

Liz Fletcher

\section{Hatch-Waxman changes debated}

The US Department of Agriculture (USDA) is expected to vote in the next few weeks on a Senate bill that would extend the patent life of some biotechnology process patents held by nonprofit organizations. The legislation is designed to extend the life of a Columbia University (New York) process patent on fundamental recombinant protein technology. Several biotechnology companies currently pay Columbia University a royalty of about $1 \%$ on sales of products made using the process-over $\$ 100$ million a year collectively-but the patent expires next month. If passed, the extension could prolong these payments and open the possibility of extended patent royalties to other nonprofit institutions in the future. Supporters of the bill say it would effectively offer universities the same compensation for regulatory delays that biotech companies currently enjoy. However, industry organizations are worried that the bill is open to misinterpretation and could make it difficult to predict future royalty obligations to non-profits.

The Drug Price Competition and Patent Term Restoration Act (35 U.S.C. \$156), commonly known as the Hatch-Waxman Act, allows any US patent owner to extend the life of a patent covering drug products (or a method of making and using the drugs) that were the subject of direct regulatory review by the Food and Drug Administration before market approval. The patent extension is designed to restore part of the patent term eroded by the lengthy regulatory review process. To be eligible, a request for extension must be filed within 60 days of the drug's regu-

Ken Chahine is vice president of business development and patent cousel at Avigen, Alameda, CA. 